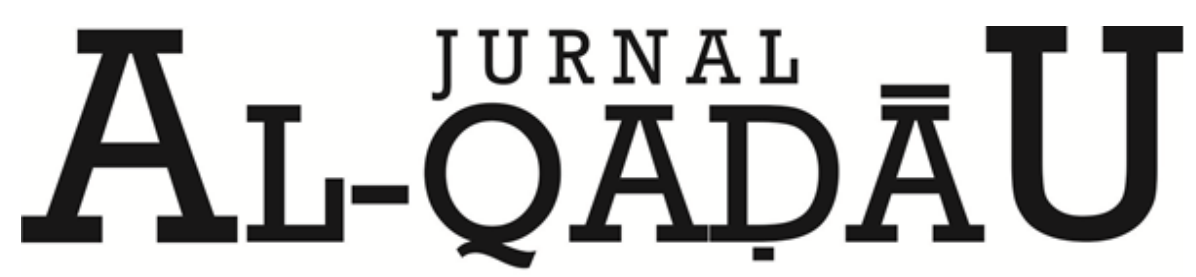

PERADILAN dan HUKUM KELUARGA ISLAM

\title{
Peranan Hakim Pengadilan Agama dalam Penerapan Hukum Islam di Indonesia
}

Religious Courts Jury role in Islamic law implementation in Indonesia

Nur Aisyah

Dosen Fakultas Syariah dan Hukum UIN Alauddin Makassar

Email: aisyahuin@gmail.com

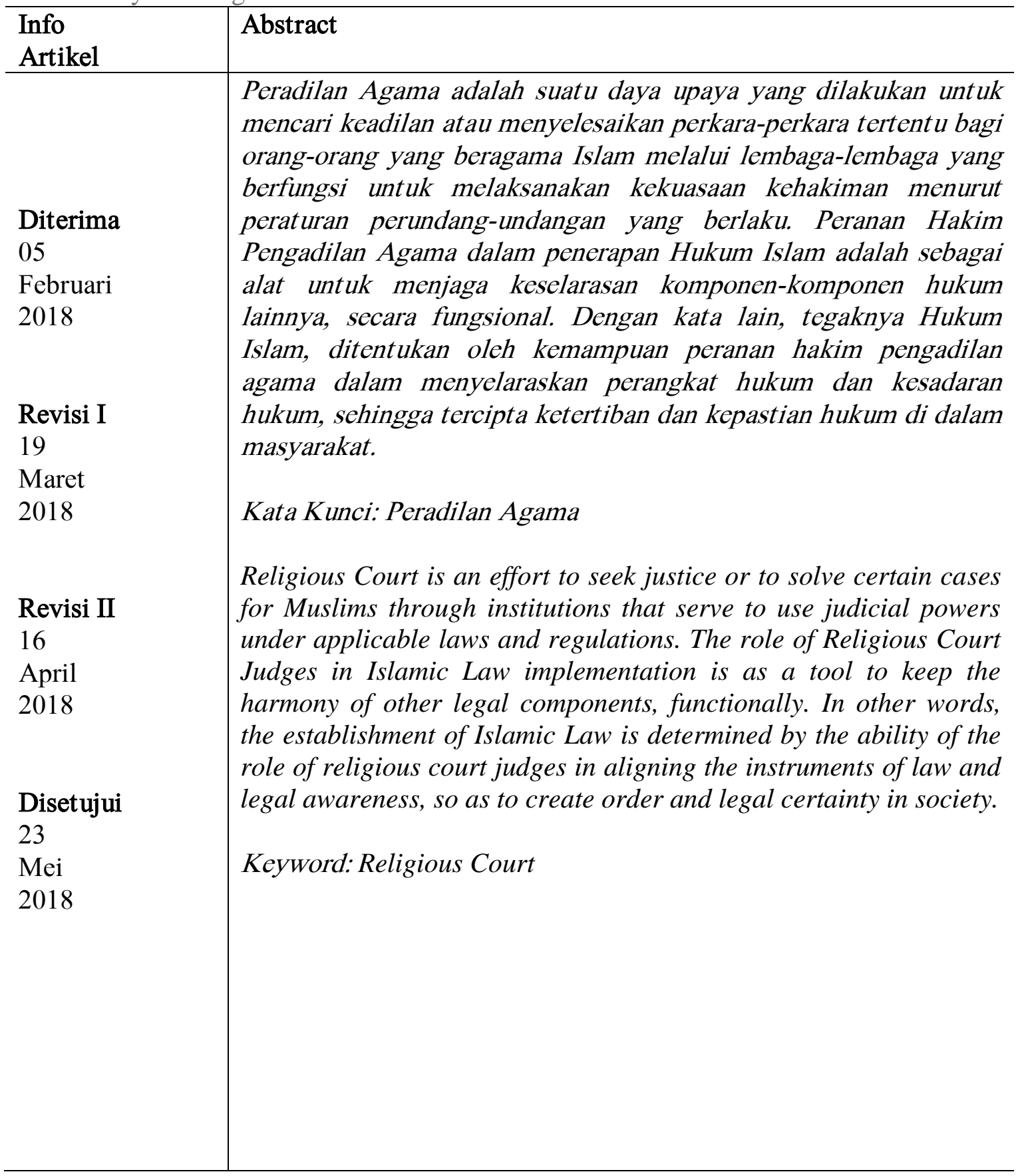


Nur Aisyah

\section{A. PENDAHULUAN}

Di masa sekarang ini hukum sedang berkembang, dan terus menerus dibangun, sementara pembangunan hukum tidak bisa meninggalkan rasa hukum masyarakatnya, tentu saja hukum Islam menjadi begitu penting peranannya dalam pembinaan Hukum Nasional Indonesia, mengingat mayoritas penduduk Indonesia adalah beragama Islam.

Indonesia yang termasuk negara yang sedang berkembang, mengawali kehidupannya dengan hasrat yang kuat untuk melaksanakan pembangunan. Yang pada dasarnya, pembangunan adalah kehendak untuk melakukan perubahan terhadap situasi kehidupan yang lebih baik, membina agar lebih maju dan memperbaiki agar lebih teratur.

Pembangunan, sebagaimana dikonsepsikan di atas, mengisyaratkan adanya perubahan terhadap dasar-dasar kemasyarakatan, baik bersifat struktural maupun kultural. Dasar-dasar kemasyarakatan tersebut, menurut Soerjono Seokanto, ${ }^{1}$ paling sedikit mencakup agama, filsafat, ideologi, ilmu pengetahuan, dan teknologi. Dengan demikian, pembangunan Hukum Islam di Indonesia dapat dirumuskan sebagai berikut:

1. Penjabaran Hukum Islam ke dalam Sistem Hukum Indonesia.

2. Penciptaan serta menyusun kembali lembaga-lembaga hukum baru.

3. Mengupayakan tentang bagaimana hukum tadi dapat dijalankan dengan efektif. ${ }^{2}$

Terciptanya suatu sistem hukum yang sesuai dengan keadaan sekarang ataupun di dalam menghadapi perkembangan di masa yang akan datang merupakan kebutuhan lain yang mendorong sifat khas permasalahan di atas.

Sesuai dengan perumusan masalah di atas, maka upaya pembangunan Hukum Islam akan melibatkan tiga komponen yang mesti diperhitungkan dengan matang dan cermat,yaitu: (1) komponen perangkat hukum, (2) komponen penegak hukum, dan (3) komponen kesadaran hukum. ${ }^{3}$

Memperhitungkan setiap komponen hukum secara menyeluruh merupakan suatu pembahasan yang lengkap dan tuntas. Akan tetapi, membatasi pembahasan terhadap komponen penegak hukum bukan berarti menganggap komponen-komponen hukum yanng lainnya kurang penting.

Berkenaan dengan ini, maka Hakim Pengadilan Agama yang terlibat secara langsung dengan proses hukum, ${ }^{4}$ akan berhadapan dengan suatu dilema persoalan. Di satu sisi, Hakim Pengadilan Agama harus memegang teguh perangkat hukum yang berlaku dan diberlakukan. Sedangkan di sisi lain, harus memperhitungkan tingkat kesadaran masyarakat terhadap perangkat hukum tersebut.

Dilema persoalan tersebut jelas, terutama, jika hukum diartikan sebagai keluaran atau hasil-aktual dari praktek sehari-hari para pejabat hukum, bukan peraturan-peraturan atau perundang-undangan. ${ }^{5}$ Meskipun demikian, perangkat hukum tetap dipergunakan. Paling tidak, sebagai pegangan dalam melukiskan proses

\footnotetext{
${ }^{1}$ Soerjono Soekanto, "Ilmu-ilmu Hukum dan Pembangunan Hukum," Analisis Pendidikan (Jakarta : Departemen Pendidikan dan Kebudayaan, 1983), h 37.

${ }^{2}$ Deden Effendi, Kompleksitas Hakim Pengadilan Agama (Jakarta : Departemen Agama R.I., 1985), h. 2.

${ }^{3}$ Deden Effendi, Kompleksitas Hakim Pengadilan Agama, h. 2.

${ }^{4}$ Soerjono Soekanto, "Ilmu-ilmu Hukum dan Pembangunan Hukum," Analisis Pendidikan, h. 40.

${ }^{5}$ Daniel S. Lev, Peradilan Agama di Indonesia: Studi tentang Landasan Politik LembagaLembaga Hukum, alih bahasa H. Zaini Ahmad Noeh (Jakarta: PT Intermasa, 1980), h. 16.
} 
Nur Aisyah

sesungguhnya dari pembangunan hukum, Pada hakikatnya, bagaimanapun hukum didefinisikan, hukum merupakan salah satu aspek budaya. Dalam hal ini hukum merupakan hasil konkritisasi manusia atas nilai-nilai agama dalam mengatur kehidupan manusia itu sendiri. ${ }^{6}$ Dengan demikian, hukum dapat dijumpai dalam berbagai lambang atau simbol.

Di antara lambang-lambang tersebut yang paling tegas dalam mengutarakan isi dan maknamya adalah dalam bentuk tertulis, "perangkat hukum formal". Dalam hal ini, hukum memperlihatkan sifatnya yang mendua, "ambivalent". Sebab, bentuk yang demikian menunjukkan adanya kepastian hukum, dan pada saat yang sama, bentuk yang demikian menunjukkan adanya kekuataan hukum.

Kepastian hukum banyak ditentukan oleh kekakuan di dalam pengaturan. Akan tetapi, pada gilirannya, kekakuan di dalam pengaturan akan menyebabkan keadaan yang lain pula, di antaranya: menciptakan ketimpangan antara bentuk pengaturan oleh perangkat hukum dengan keadaan, hubungan, dan peristiwa-peristiwa dalam masyarakat.

Oleh karena itu, dalam mencari tempat berpijak yang memungkinkan terjaminnya proses pembangunan hukum, Hakim Pengadilan Agama dihadapkan pada suatu persoalan yang bersifat dilematis. Karena, keterlibatan Hakim Pengadilan Agama terhadap salah satu ekstrema yang dilaksanakan secara berlebihan dapat mengakibatkan penyimpamgan terhadap tujuan hukum itu sendiri, "keadilan". Sebab, di satu pihak, menganggap perangkat hukum (formal) sebagai gejala yang berdiri sendiri berarti mengabaikan situasi umum kehidupan masyarakat.

Hubungan antara hukum dan masyarakat bersifat timbal-balik atau dialektis. Hukum memberi penilaian terhadap masyarakat dan juga mengarahkan apa yang seharusnya mereka lakukan mengenai kedudukan mereka dan masyarakat memberikan dasar-dasar sosial. Tetapi yang sering terjadi di dalam masyarakat, ukuran yang diusulkan tidak sesuai dengan kenyataan yang dihadapi atau biasa diartikan sebagi masalah sosial. ${ }^{7}$

Dengan demikian, langsung atau tidak langsung, permasalahan sosial tersebut berhubungan dengan peran yang dimainkan oleh hakim pengadilan Agama. Hakim pengadilan Agama memberi dan menentukan prosedur yang harus ditempuh dalam mencapai tujuan yang diharapkan oleh masyarakat. Oleh karena itu, peranan hakim pengadilan Agama adalah untuk memelihara keselarasan fungsional dari komponenkomponen hukum lainnya.

Istilah "Peranan" (role) ${ }^{8}$ dipilih karena menyatakan bahwa setiap orang adalah pelaku di dalam masyarakat di mana dia hidup. Dan maksud konsep "peranan" adalah untuk membuat garis batas antara masyarakat dan individu. Dalam batas peranan sosialnya, seorang mempunyai batas kebebasan tertentu. ${ }^{9}$

30

${ }^{6}$ T. M. Hasbi Ash Shiddiqi, Peradilan Hukum Acara Islam (Bandung: PT Al-Maarif, 1964), h.

${ }^{7}$ Deden Effendi, Kompleksitas Hakim Pengadilan Agama, h. 6.

${ }^{8}$ Menurut Bambang Marhijanto, Kata peranan berarti juga sebagai bagian dari tugas yang harus dilaksanakan. Lihat Bambang Marhijanto, Kamus Lengkap Bahasa Indonesia Populer (Surabaya: CV. Bintang Timur, 1996), h. 476.

${ }^{9}$ Maurice Duverger, Sosiologi Politik, alih bahasa Daniel Dhakidae (Jakarta: CV Rajawali, 1981), h. 103. 
Nur Aisyah

Dalam hal ini, hakim pengadilan Agama adalah termasuk pelaku dan mempunyai tingkat kebebasan tertentu dalam menyatakan hasrat untuk diakui serta diperhitungkan pengaruhnya sebagai sesuatu hal yang penting dalam masyarakat. Selain itu, Peranan juga mempunyai arti lebih luas dari pada tugas. Tugas adalah suatu kewajiban yang harus dilaksanakan atau sesuatu yang wajib dikerjakan. Tugas seorang hakim agama adalah memeriksa, mengadili dan memutus perkara, dan fungsinya adalah menegakkan kebenaran dan keadilan. Sedangkan peran hakim adalah menjalankan semua tugas, fungsi dan tanggung jawab yang diembannya. Berdasarkan latar belakang tersebut, maka dapat di tarik beberapa rumusan masalah, yakni bagaimana tugas, fungsi, kedudukan, dan kewajiban hakim di lingkungan badan peradilan agama dan bagaimana kontribusi hakim pengadilan agama dalam penerapan hukum Islam.

\section{B. PEMBAHASAN}

\section{TUGAS, FUNGSI, KEDUDUKAN, DAN KEWAJIBAN HAKIM DI LINGKUNGAN BADAN PERADILAN AGAMA}

\section{Tugas Hakim}

Pengaruh peradilan, tugas hakim adalah mempertahankan tata hukum, menetapkan apa yang ditentukan oleh hukum dalam suatu perkara. Dengan demikian yang menjadi tugas pokoknya adalah menerima, memeriksa, dan mengadili serta menyelasaikan setiap perkara yang diajukan kepadanya.

Dari banyaknya masalah yang ada, tidak semuanya ada peraturan perundangundangannya yang mengatur masalah tersebut. Untuk mengatasi masalah hal ini hakim tidak perlu untuk selalu berpegang pada peraturan-peraturan yang tertulis saja, dalam keadaan demikian tepatlah apabila hakim diberi kebebasan untuk mengisi kekosongan hukum. Untuk mengatasi masalah tersebut hakim dapat menyelesaikannya dengan memperhatikan hukum yang hidup dalam masyarakat atau yang dikenal dengan hukum adat. Sehingga dengan demikian tidak akan timbul istilah yang dikenal dengan sebutan kekosongan hukum. Kewenangan hakim untuk melakukan hal demikian ini sesuai pula dengan apa yang telah ditentukan dalam pasal 16 ayat (1) UU No. 48 Tahun 2009.

Dengan melihat kenyataan di atas, maka tampak jelas bahwa dalam hal ini hakim harus aktif dari permulaan sampai akhir proses, bahkan sebelum proses dimulai, yaitu pada waktu penggugat mengajukan gugatan, hakim telah memberikan pertolongan kepadanya. Sedangkan setelah proses berakhir, hakim memimpin eksekusi.

Aktifnya hakim dapat dilihat dari misalnya dengan adanya usaha dari hakim untuk mendamaikan dari kedua belah pihak. Bentuk yang lain misalnya, tindakan hakim untuk memberikan penerangan selayaknya kepada para pihak yang berperkara tentang upaya-upaya hukum apa yang dapat mereka lakukan, atau tentang pengajuan alat-alat bukti, sehingga dengan demikian pemeriksaan dapat berjalan dengan lancar.

Selain bersifat aktif, hakim bersifat pula pasif, dalam arti bahwa ruang lingkup atau luas pokok sengketa yang diajukan kepada hakim untuk diperiksa pada asasnya ditentukan oleh para pihak yang berperkara dan bukan oleh hakim. Hakim hanya membantu para pencari keadilan dan mengatasi segala hambatan dan rintangan untuk dapat tercapainya keadilan. Dalam hal ini, para pihak dapat secara bebas mengakhiri sengketa yang telah diajukan ke muka pengadilan, sedang hakim tidak dapat menghalang-halanginya, hal ini dapat dilakukan dengan jalan perdamaian atau 
pencabutan gugatan. Dengan demikian hakim tidak menentukan luas dari pokok sengketa, yang berarti hakim tidak boleh menambah atau menguranginya.

Dari sini dapat disimpulkan, bahwa hakim bersifat aktif kalau ditinjau dari segi demi kelancaran persidangan, sedangkan hakim bersifat pasif kalau ditinjau dari segi luasnya tunt utan.

Tugas hakim pengadilan agama di dalam mewujudkan keadilan berdasarkan Ketuhanan Yang Maha Esa, bukan sekedar berperan memantapkan kepastian hukum, melainkan juga keadilan. ${ }^{10}$

Dalam penjelasan atas Undang-undang No. 48 Tahun 2009 tentang Kekuasaan Kehakiman Pasal 1, dijelaskan:

Kebebasan dalam melaksanakan wewenang yudisial bersifat tidak mutlak karena tugas hakim adalah untuk menegakkan hukum dan keadilan berdasarkan Pancasila, sehingga put usannya mencerminkan rasa keadilan rakyat Indonesia.

Dicantumkannya pernyataan itu pada pada penjelasan undang-undang dimaksudkan agar mata, hati, dan telinga hakim terbuka terhadap berbagai tuntutan yang berkembang dalam masyarakat. Dengan demikian, dalam melaksanakan kewajibannya, ia tidak hanya berdasarkan hukum, tetapi berdasarkan keadilan yang diucapkan atas nama Tuhan Yang Maha Esa.

Disamping yang lahiriyah, terdapat tanggung jawab hakim yang bersifat batiniah, yaitu:

Bahwa karena sumpah jabatannya, dia tidak hanya bertanggung jawab pada hukum, kepada diri sendiri, dan kepada rakyat, tetapi bertanggung jawab kepada Tuhan Yang Maha Esa, yang dalam Undang-undang ini dirumuskan dengan ketentuan bahwa pengadilan dilakukan, 'Demi keadilan berdasarkan Ketuhanan Yang Maha Esa'. ${ }^{11}$

\section{Fungsi Hakim}

Fungsi hakim adalah menegakkan kebenaran sesunggyuhnya dari apa yang dikemukakan dan dituntut oleh para pihak tanpa melebihi atau menguranginya terutama yang berkaitan dengan perkara perdata, sedangkan dalam perkara pidana mencari kebenaran sesungguhnya secara mutlak tidak terbatas pada apa yang telah dilakukan oleh terdakwa, ${ }^{12}$ melainkan dari itu harusdiselidiki dari latar belakang perbuatan terdakwa. Artinya hakim pengejar kebenaran materil secara mutlak dan tuntas.

Di sini terlihat intelektualitas hakim yang akan teruji dengan dikerahkannya segenap kemampuan dan bekal ilmu pengetahuan yang mereka miliki, yang semua itu akan terlihat pada proses pemeriksaan perkara apakah masih derdapat pelanggaranpelanggaran dalam teknis yustisial atau tidak.

\footnotetext{
${ }^{10}$ Hal ini secara resmi tercantum dalam pasal 4 ayat (1) UU No. 48 Tahun 2009 tentang Ketentuan-ketentuan Pokok Kekuasaan Kehakiman: "Demi keadilan berdasarkan Ketuhanan Yang Maha Esa”.

${ }^{11}$ Penjelasan UU No. 14 Tahun 1970, I umum, butir enam, alinea terakhir.

${ }^{12}$ Abdul Kadir Muhammad, Hukum Acara Perdata Indonesia (Bandung: Citra Aditya Bakti, 1992), h. 37.
} 
Nur Aisyah

\section{Kedudukan Hakim}

Kedudukan hakim adalah sebagai pejabat yang melakukan kekuasaan kehakiman yang diatur dalam undang-undang. ${ }^{13}$ Hakim juga harus memiliki integritas dan kepribadian yang tidak tercela, jujur, adil, professional, dan berpengalaman dalam bidang hukum, dan bagi soerang hakim dituntut dalam menjalankan tugas dan fungsinya, hakim wajib menjaga kemandirian peradilan.

\section{Kewajiban Hakim}

Adapun kewajiban hakim menurut Undang-undang No. 48 Tahun 2009 sebagi pengganti UU No. 14 tahun 1970 adalah:

1) Memutus demi keadilan berdasarkan Tuhan Yang Maha Esa. Hal ini sesuai dengan Pasal 29 Undang-Undang Dasar Negara Republik Indonesia Tahun 1945 yang menentukan : a) Negara berdasarkan atas Ketuhanan Yang Maha Esa, b) Negara menjamin kemerdekaan tiap-tiap penduduk untuk memeluk agama masing-masing dan untuk beribadat menurut agamanya dan kepercayaannya itu (pasal 4 ayat 1 ).

2) Menggali, mengikuti, dan memahami nilai-nilai hukum dan rasa keadilan yang hidup di dalam masyarakat. Ketentuan ini dimaksudkan agar putusan hakim sesuai dengan hukum dan rasa keadilan masyarakat (pasal 28 ayat 1 ).

3) Dalam mempertimbangkan berat ringannya hukuman, hakim wajib memberhatikan pula sifat yang baik dan jahat dari terdakwa. Berdasarkan ketentuan ini maka dalam menentukan berat ringannya hukuman yang akan dijatuhkan hakim wajib memperhatikan sifat baik atau sifat jahat dari terdakwa sehingga putusan yang dijatuhkan setimpal dan adil sesuai dengan kesalahannya (pasal 28 ayat 2).

Dengan demikian tugas hakim adalah melaksanakan semua tugas yang menjadi tanggung jawabnya untuk memberikan kepastian hukum semua perkara yang masuk, baik perkara tersebut telah di atur dalam undang-undang maupun yang tidak terdapat dalam ketentuannya. Di sini terlihat dalam menjalankan tanggung jawabnya, hakim harus bersifat obyektif, karena merupakan fungsionaris yang ditunjuk undangundanguntuk memeriksa dan menggali perkara dengan penilaian yang obyektif pula, karena harus berdiri di atas kedua belah pihak yang berperkara dan tidak boleh memihak salah satu pihak.

\section{Kewenangan Pengadilan Agama}

Kewenangan disebut juga kekuasaan atau kompetensi, kompetensi berasal dari bahasa Latin competo, kewenangan yang diberikan undang-undang mengenai batas untuk melaksanakan sesuatu tugas; wewenang mengadili. Kompetensi dalam bahasa Belanda disebut competentie, kekuasaan (akan) mengadili; kompetensi. Kompetensi disebut juga kekuasaan atau kewenangan mengadili yang berkaitan dengan perkara yang diperiksa di pengadilan atau pengadilan mana yang berhak memeriksa perkara tersebut. Ada dua macam kompetensi ata kekuasaan/kewenangan mengadili, yaitu kewenangan relatif dan kewenangan absolut.

\footnotetext{
${ }^{13}$ UU No. 48 Tahun 2009 tentang Kekuasaan Kehakiman (Surabaya: Karina, 2004) h. 35.
} 


\section{1). Kewenangan Relatif Peradilan Agama}

Yang dimaksud dengan kekuasaan relatif (relative competentie) adalah pembagian kewenangan atau kekuasaan mengadili antar Pengadilan Negeri. Atau dengan kata lain Pengadilan Negeri mana yang berwenang memeriksa dan memutus perkara. Pengertian lain dari kewenangan relatif adalah kekuasaan peradilan yang satu jenis dan satu tingkatan, dalam perbedaannya dengan kekuasaan pengadilan yang sama jenis dan tingkatan. Misalnya antara Pengadilan Negeri Bogor dan Pengadilan Negeri Subang, Pengadilan Agama Muara Enim dengan Pengadilan Agama Baturaja.

Dari pengertian di atas maka pengertian kewenangan relatif adalah kekuasaan atau wewenang yang diberikan kepada pengadilan dalam lingkungan peradilan yang sama jenis dan tingkatan yang berhubungan dengan wilayah hukum Pengadilan dan wilayah tempat tinggal/tempat kediaman atau domisili pihak yang berperkara.

\section{(1). Kewenangan Relatif Perkara Gugatan} meliputi:

Pada dasarnya setiap gugatan diajukan ke Pengadilan yang wilayah hukumnya

- gugatan diajukan kepada pengadilan yang wilayah hukumnya meliputi wilayah kediaman tergugat. Apabila tidak diketahui tempat kediamannya maka pengadilan di mana tergugat bertempat tinggal;

- apabila tergugat lebih dari satu orang maka gugatan dapat diajukan kepada pengadilan yang wilayah hukumnya meliputi wilayah salah satu kediaman tergugat;

- apabila tempat kediaman tergugat tidak diketahui atau tempat tinggalnya tidak diketahui atau jika tergugat tidak dikenal (tidak diketahui) maka gugatan diajukan ke pengadilan yang wilayah hukumnya meliputi tempat tinggal penggugat;

- apabila objek perkara adalah benda tidak bergerak, gugatan dapat diajukan ke pengadilan yang wilayah hukumnya meliputi letak benda tidak bergerak.

- Apabila dalam suatu akta tertulis ditentukan domisili pilihan, gugatan diajukan kepada pengadilan yang domisilinya dipilih.

\section{(2). Kewenangan Relatif Perkara Permohonan}

Untuk menentukan kekuasaan relatif Pengadilan Agama dalam perkara permohonan adalah diajukan ke pengadilan yang wilayah hukumnya meliputi kediaman pemohon. Namun dalam Pengadilan Agama telah ditentukan mengenai kewenangan relatif dalam perkara-perkara tertentu, perkara-perkara tersebut adalah sebagai sebagai berikut.

- Permohonan ijin poligami diajukan ke Pengadilan Agama yang wilayah hukumnya meliputi kediaman pemohon.

- Permohonan dispensasi perkawinan bagi calon suami atau istri yang belum mencapai umur perkawinan (19 tahun bagi laki-laki dan 16 tahun bagi perempuan) diajukan oleh orang tuanya yang bersangkutan kepada Pengadilan Agama yang wilayah hukumnya meliputi kediaman pemohon.

- Permohonan pencegahan perkawinan diajukan ke Pengadilan Agama yang wilayah hukumnya meliputi tempat pelaksanaan perkawinan. 
Nur Aisyah

- Permohonan pembatalan perkawinan diajukan kepada Pengadilan Agama yang wilayah hukumnya meliputi tempat dilangsungkannya pernikahan atau tempat tinggal suami atau istri.

\section{2). Kewenangan Absolut Peradilan Agama}

Kewenangan absolut (absolute competentie) adalah kekuasaan yang berhubungan dengan jenis perkara dan sengketa kekuasaan pengadilan. Kekuasaan pengadilan di lingkungan Peradilan Agama adalah memeriksa, memutus, dan menyelesaikan perkara perdata tertentu di kalangan golongan rakyat tertentu, yaitu orang-orang yang beragama Islam. Kekuasaan absolut Pengadilan Agama diat ur dalam pasal 49 Undang-Undang Nomor 3 Tahun 2006 tentang Perubahan Atas UndangUndang Nomor 7 Tahun 1989 tentang Peradilan Agama yang pada pokoknya adalah sebagai berikut. Perkawinan, waris, wasiat, hibah, wakaf, zakat, infaq, shadaqah dan ekonomi syari' $a h^{14}$.

Dalam penyelenggaraan kekuasaan kehakiman (judicial power) di Indonesia dilaksanakan oleh sebuah Mahkamah Agung dan badan peradilan yang di bawahnya dalam lingkungan Peradialn Umum, Peradilan Agama, Peradilan Militer dan Peradilan Tata Usaha Negara, dan oleh sebuah Mahkamah konstitusi. ${ }^{15}$ Pada masing-masing lingkungan peradilan itu memiliki cakupan dan wewenang sendiri-sendiri untuk mengadili (atributie van rechtmacht), dan ditentukan oleh oleh bidang yurisdiksi yang dilimpahkan undang-undang kepadanya.

Kekuasaan atau wewenang pengadilan pada masing-masing lingkungan terdiri atas wewenang relative (relative competentie) dan wewenang mutlak (absolute competentie). ${ }^{16}$ Wewenang relative berhubungan dengan daerah hukum suatu pengadilan, baik pengadilan tingkat pertama maupun pengadilan tingkat banding. Artinya, cakupan dan batasan kekuasaan relative Pengadilan ialah meliputi daerah hukumnya berdasarkan undang-undang.

Daerah hukum dari Pengadilan Agama meliputi wilayah kotamadya atau kabupaten, dan daerah hukum dari Pengadilan Tinggi Agama Agama meliputi wilayah propinsi.

Sedangkan wewenang mutlak berkenaan dengan jenis perkara dan jenjang pengadilan. Wewenang Pengadilan Agama itu diatur dalam Bab III pasal 49 sampai dengan pasal 53 Undang-Undang Nomor 7 Tahun 1989. dan di dalam ketentuan pasal 49 dinyatakan:

(1) Pengadilan Agama bertugas dan berwenang memeriksa, memutus, dan menyelesaikan perkara-perkara di tingkat pertama antara orang-orang yang beragama Islam di bidang: a. perkawinan, b. kewarisan, wasiat, dan hibah, yang dilakukan berdasarkan hukum Islam, c. wakaf dan shadaqah.

(2) Bidang perkawinan sebagaimana yang dimaksud dalam ayat (1) huruf a ialah hal-hal yang diatur dalam atau berdasarkan undang-undang mengenai perkawinan yang berlaku.

\footnotetext{
${ }^{14}$ http://advosolo.wordpress.com/2010/05/15/kekuasaan-peradilan-agama/

${ }^{15}$ UU No. 48 Tahun 2009 tentang Kekuasaan Kehakiman (Surabaya: Karina, 2004) h. 26.

${ }^{16}$ Cik Hasan Bisri, Peradilan Agama Di Indonesia (Cet. II (Jakarta: PT. RajaGrafindo Persada,1998). h. 204.
} 
(3) Bidang kewarisan sebagaimana yang dimaksud dalam ayat (1) huruf b ialah penentuan siapa-siapa yang menjadi ahli waris, penentuan mengenai harta peninggalan, penentuan masing-masing bagian ahli waris, dan melaksanakan pembagian harta peninggalan tersebut.

\section{KONTRIBUSI HAKIM PENGADILAN AGAMA DALAM PENERAPAN HUKUM ISLAM}

\section{Sumber-Sumber Putusan Hakim}

Alasan hukum yang menjadi dasar pertimbangan bertitik tolak dari ketentuan sebagai berikut; pasal-pasal tertentu dari peraturan perundang-undangan, hukum kebiasaan, yurisprudensi dan doktrin hukum. Sebagaimana Pasal 23 UU No. 14 Tahun 1970, sebagaimana diubah dengan UU No. 35 Tahun 1999 sekarang dalam Pasal 25 ayat (1) UU No. 48 Tahun 2009 menegaskan bahwa segala putusan pengadilan harus memuat alasan-alasan dan dasar-dasar putusan dan mencantumkan pasal-pasal peraturan perundang-undangan tertentu yang bersangkutan dengan perkara yang diputus atau berdasarkan hukum tak tertulis maupun yurisprudensi atau doktrin hukum. ${ }^{17}$

Abdul Manan menyebutkan bahwa dalam pertimbangan hukum, seorang hakim setelah mempertimbangkan dalil gugatan, bantahan atau eksepsi dari Tergugat serta dihubungkan dengan bukti- bukti yang ada lalu menarik kesimpulan dari semua hal tersebut diatas, selanjutnya seorang hakim menuliskan dalil-dalil hukum syara yang menjadi sandaran pertimbangannya dengan mengutamakan dalil yang bersumber dari al-Qur'an dan al-Hadits, baru pendapat para ulama yang terdapat dalam kitab-kitab fiqh. ${ }^{18}$

Pendapat para ulama yang terdapat dalam kitab-kitab fiqh merupakan salah satu diantara sumber-sumber hukum acara di Peradilan Agama. ${ }^{19}$ Namun dalam rangka unifikasi hukum berdasarkan Surat Edaran Biro Peradilan Agama Departemen Agama Nomor B/1/1735, tanggal 18 Februari 1958 sebagai pelaksana Peraturan Pemerintah Nomor 45 Tahun 1957 tentang pengadilan luar Jawa dan Madura, kitab fiqh yang dapat dijadikan pedoman hukum acara ada 13 yaitu sebagai berikut; al-Bajuri, Fatchul Mu'in, Syarqowi 'ala Tahrir, Qalyubi/Mahalli, Fathul Wahhab dan Syarahnya, Tuhfah, Targhibul Musytaq, Qawaninus Syari'ah Lis Sayyid bin Yahya, Qawaninus Syari'ah Lis Sayyid Sadaqah Dahlan, Syamsuri fil Faraidh, Bugyatul Mustarsyidin, al-Fiqh 'ala Madzahib Arba'ah dan Mugnil Muhtaj. ${ }^{20}$

Salah satu keistimewaan dan perbedaan putusan pengadilan agama dengan yang lainnya adalah adanya doktrin-doktrin dari qur'an, hadits dan aqwal fuqaha. Karenanya jika kita meneliti putusan-putusan yang terdapat pada buku yurisprudensi terutama

\footnotetext{
${ }^{17}$ Yahya Harahap, Hukum Acara Perdata tentang Gugatan, Persidangan, Penyitaan, Pembuktian dan Putusan Pengadilan (Cet.II; Sinar Grafika, Jakarta, 2005), h. 798.

${ }^{18}$ Abdul Manan, Penerapan Hukum Acara Perdata di Lingkungan Peradilan Agama (Cet.II; Yayasan al-Hikmah, Jakarta, 2001), h. 200.

${ }^{19}$ Ahmad Mujahidin, Pembaruan Hukum Acara Perdata Peradilan Agama dan Mahkamah Syari'ah di Indonesia (Cet.I; IKAHI, Jakarta, 2008), h. 41.

${ }^{20}$ Ahmad Mujahidin, Pembaruan Hukum Acara Perdata Peradilan Agama dan Mahkamah Syari'ah di Indonesia.
} 
Nur Aisyah

buku yurisprudensi lama, kita akan menemukan banyak sekali dalil-dalil qur'an, hadits maupun aqwal fuqaha yang dijadikan sandaran pertimbangan dalam putusan. Dalam makalah ini, penulis berusaha mengumpulkan dan menginventarisir dalil-dalil baik dari al-Qur'an, hadits maupun aqwal fuqaha yang penulis dapatkan dari beberapa yurisprudensi putusan Pengadilan Agama yang ada pada penulis dengan harapan bisa bermampaat bagi para pihak yang membutuhkannya terutama para hakim dalam lingkungan peradilan agama.

Dalil-dalil dari Qur'an

1). QS. al-Maidah ayat 1, yang berbunyi:

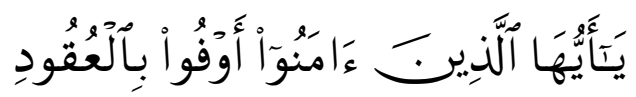

Terjemahnya:

Wahai orang-orang yang beriman, penuhilah akad-akad itu.

Ayat ini terdapat dalam pertimbangan putusan perkara nomor: 1047/Pdt.G/2006/PA.Pbg tentang perkara gugatan pemenuhan kewajiban akad pembiayaan al-Musyarakah ${ }^{21}$

2). QS. an-Nur ayat 6-7 yang berbunyi:

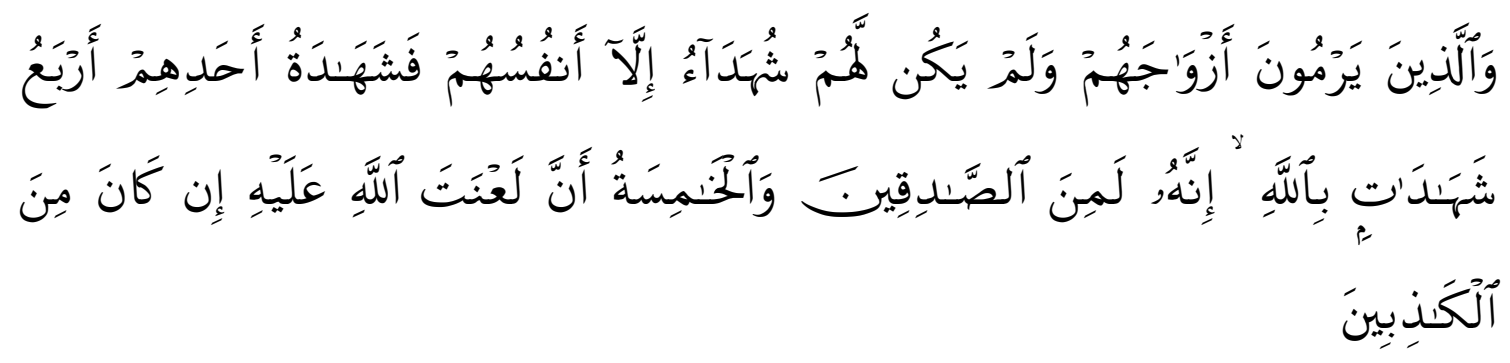

Terjemahnya:

Dan orang-orang yang menuduh istrinya berbuat zina padahal mereka tidak mempunyai saksi-saksi selain diri mereka sendiri, maka persaksian orang itu ialah empat kali bersumpah dengan nama Allah, sesungguhnya dia termasuk orang yang benar(6) Dan sumpah yang kelima bahwa laknat Allah atasnya, jika dia termasuk orang-orang yang berdusta.

Ayat diatas terdapat dalam Putusan Nomor: 505/1984 Pengadilan Agama Istimewa Jakarta Raya dalam perkara gugat cerai. ${ }^{22}$

3) QS. al-Ruum Ayat. 21 yang berbunyi:

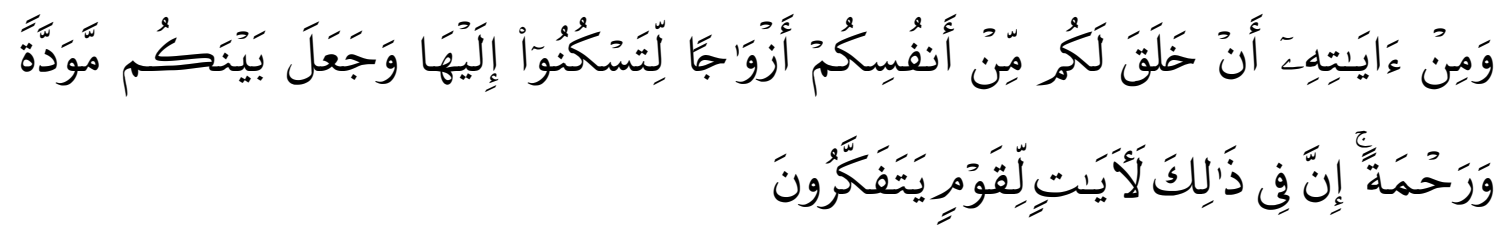

${ }^{21}$ Mimbar Hukum Islam No.66 Desember 2008, h, 182.

${ }^{22}$ Departemen Agama RI, Berita Acara Persidangan Peradilan Agama, Direktorat Jenderal Pembinaan Kelembagaan Agama Islam,cet.1 th. 1987, h, 42 
Terjemahnya:

Dan diantara tanda-tanda kekuasaan Allah ialah, Dia menciptakan untukmu isteri-isteri dari dirimu sendiri, supaya kamu cenderung dan merasa tentram kepadanya, dan dijadikan diantaramu rasa kasih sayang. Sesungguhnya pada yang demikian itu benar-benar terdapat bagi tanda-tanda bagi kaum yang berakal.

Ayat diatas terdapat dalam Putusan Nomor:283/1985 Pengadilan Agama Jakarta Barat dalam perkara cerai gugat. ${ }^{23}$

4) QS. al-Baqarah ayat 227 yang berbunyi:

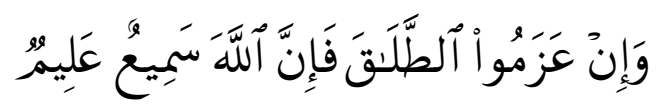

Terjemahnya:

Dan jika mereka berajam (berketetapan hati) talak maka sesungguhnya Allah Maha Mendengar lagi Maha Melihat.

Ayat ini terdapat dalam pertimbangan putusan Nomor: 63/Pdt.G/1999/PA.SRG tentang perkara cerai talak. ${ }^{24}$

5) QS. an-Nisa ayat 35, yang berbunyi:

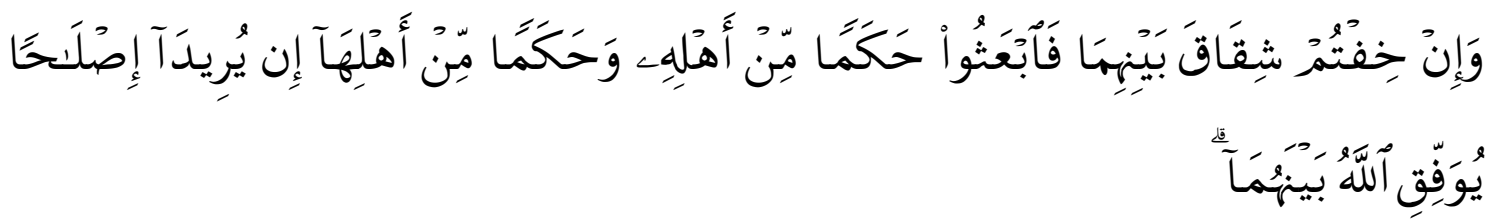

Terjemahnya:

Dan jika kamu khawatirkan adanya persengketaan diantara keduanya, maka utuslah seorang hakam dari keluarga laki-laki dan seorang hakam dari keluarga perempuan. Jika kedua hakam bermaksud mengadakan perbaikan (ishlah), niscaya Allah memberi taufiq kepada keduanya".

\section{Pola Pengambil Putusan Hakim}

Bahwa tertib administrasi perkara adalah merupakan bagiaan dari Court Of Law yang mutlak harus dilaksanakan oleh semua aparat peradilan agama dalam rangka mewujudkan Peradilan yang mandiri sesuai dengan peraturan yang berlaku. Hal ini dapat terlaksana apabila aparat Peradilan Agama memahami pengertian administrasi secara luas. Dalam kepustakaan banyak dikenal pengertian administrasi yang banyak ditulis oleh para pakar, tetapi yang dimaksud administrasi dalam tulisan ini adalah suatu proses penyelenggaraan oleh seorang administratur secara teratur dan diat ur guna melakukan perencanaan, pelaksanaan dan pengawasan untuk mencapai tujuan pokok

\footnotetext{
${ }^{23}$ Departemen Agama RI, Berita Acara Persidangan Peradilan Agama, Direktorat Jenderal Pembinaan Kelembagaan Agama Islam,cet.1 th. 1987, h, 42

${ }^{24}$ Yurisprudensi MARI, tahun 2003, h, 111
} 
yang telah ditetapkan semula. Yang dimaksud dengan proses adalah kegiatan yang dilaksanakan secara beruntun dan susul-menyusul, artinya selesai yang satu harus diikuti dengan pekerjaan yang lain sampai titik akhir. Proses itu sendiri meliputi enam hal yaitu : menghimpun, mencatat, mengolah, menggandakan, mengirim dan penyimpan. Sedangkan yang dimaksud dengan diatur adalah seluruh kegiatan itu harus disusun dan disesuaikan satu sarna lainnya supaya terdapat keharmonisan dan kesinambungan tugas. Adapun yang dimaksud dengan teratur adalah kegiatan perencanaan, pelaksanaan dan pengawasan yang dilaksanakan secara terus menerus dan terarah sehingga tidak terjadi tumpang tindih (overlap) dalam melaksanakan tugas, sehingga akan mencapai penyelesaian tugas pokok secara maksimal. Peradilan Agama, sebagaimana ditegaskan dalam Pasal 2 UU Nomor 3 Tahun 2006, adalah salah satu pelaku kekuasaan kehakiman bagi rakyat pencari keadilan yang beragama Islam mengenai perkara tertentu. Tugas pokoknya adalah memeriksa, memutus, dan menyelesaikan perkara di tingkat pertama antara orang-orang yang beragama Islam di bidang : perkawinan, waris, wasiat, hibah, wakaf, zakat, infaq, shadaqah dan ekonomi syari'ah (Pasal 49 UU 3/2006). Yang melaksanakan tugas-tugas administrasi dalam rangka mencapai tugas pokok tersebut adalah Panitera, sebagaimana tersebut dalam pasal 26 Undang-undang Nomor 7 Tahun 1989 jo UU Nomor 3 Tahun 2006. Panitera sebagai pelaksana kegiatan administrasi Pengadilan memiliki 3 (tiga) macam tugas :

1. Pelaksana Administrasi Perkara...

2. Pendamping Hakim dalam persidangan

3. Pelaksana Putusan/Penetapan Pengadilan dan Tugas-tugas Kejurusitaan lainnya.

Sebagai pelaksana administrasi perkara Panitera berkewajiban mengatur tugas dan para pembantunya, yakni Wakil Panitera dan Panitera Muda. Sebagai pendamping Hakim/Majelis dalam persidangan Panitera berkewajiban mencatat jalnnya persidangan dan dari catatan-catatan tersebut, hendaknya disusun berita acara persidangan. Dalam hal Panitera berhalangan maka Panitera dibantu oleh para Panitera Pengganti. Sebagai pelaksana putusan dan pelaksana tugas

kejurusitaan lainnya, panitera dibantu oleh Jurusita Pengadilan Agama atau Juru Sita Pengganti.

Untuk Panitera Pengadilan Tinggi Agama, tugas Pelaksana Putusan/Penetapan Pengadilan tidak diatur. Hal ini karena sebagai peradilan tingkat banding Pengadilan Tinggi Agama tidak melaksanakan tugas-tugas kejurusitaan dan Eksekusi. Sebagai pelaksana administrasi perkara Panitera berkewajiban untuk melaksanakan dengan tertib ketentuan seperti tersebut dalam pasal 99 Undang- Undang Nomor 7 tahun 1989 jo Undang-undang Nomor 3 Tahun 2006 yaitu membuat daftar semua perkara yang diterima kepaniteraan serta memberi nomor urut dan dibubuhi catatan singkat tentang isinya. Adapun tanggung jawab Panitera adalah sebagaimana dalam pasal 101 UU No. 7 Tahun 1989 jo UU No 3 Tahun 2006 yaitu bertanggung jawab atas pengurusan perkara, penetapan atau putusan. dokumen, akta, buku daftar, biaya perkara. uang titipan pihak ketiga, surat-surat berharga, barang bukti, dan surat-surat lain yang disimpan di kepaniteraan. Dalam rangka pelaksanaan tugas pokok pengadilan Panitera menerima perkara yang diajukan kepada Pengadilan Agama untuk diproses lebih lanjut. Prosedur penerimaan perkara di Pengadilan Agama melalui beberapa meja, yaitu meja I, meja II dan meja III. Pengertian meja tersebut adalah merupakan kelompok 
pelaksana teknis yang harus dilalui oleh suatu perkara di Pengadilan Agama, mulai dari penerimaan sampai perkara tersebut di selesaikan.

1) Menerima gugatan, permohonan, perlawanan (Verzet), pernyataan banding, kasasi, permohonan peninjauan kembali, eksekusi, penjelasan dan penaksiran biaya perkara dan biaya eksekusi.

2) Membuat surat kuasa untuk membayar (SKUM) dalam rangkap tiga dan menyerahkan SKUM tersebut kepada calon penggugat atau pemohon.

3) Menyerahkan kembali surat gugatan/permohonan kepada calon penggugat/pemohon.

4) Menaksir biaya perkara sebagai ditetapkan dalam pasal $121 \mathrm{HIR} / 145 \mathrm{RBg}$ yang kemudian dinyatakan dalam SKUM. Dalam perkara cerai talak, dalam menaksir biaya-biaya perkara diperhitungkan juga untuk keperluan pemanggilan sidang Ikrar Talak.

5) Penerimaan perkara perlawanan (Verzet) hendaknya dibedakan antara perlawanan (Verzet) terhadap put usan Verstek dengan perlawanan pihak ketiga (Darden V erzet).

6) Penerimaan Verzet terhadap putusan Verstek tidak diberi nomar baru. sedang perlawanan pihak ketiga (Darden Verzet) dicatat sebagai perkara baru dan mendapat nomor baru sebagai perkara gugatan.

7) Dengan demikian penerimaan perkara secara keseluruhan meliputi:

(1) Perkara Permohonan

(2) Perkara Gugatan

(3) Perkara Banding

(4) Perkara Kasasi

(5) Perkara PK

(6) Perkara Eksekusi

8) Selain tugas-tugas penerimaan perkaraseperti tersebut di atas, maka meja pertama berkewajiban memberi penjelasan-penjelasan yang dianggap perlu berkenaan dengan perkara yang diajukan.

9) Dalam memberi penjelasan hendaknya dihindarkan dialog yang tidak periu dan untuk itu supaya diperhatikan surat Ketua Muda Mahkamah Agung RI Urusan Lingkungan Peradilan Agama tanggai 11 lanuari 1994, Nomor: MA/KumdiI/012/I/K/1994.

\section{KHI dan UU Perkawinan}

\section{Menurut KHI}

Kehadiran KHI merupakan rangkaian dari fenomena sejarah hukum nasional yang dapat mengungkap makna ganda kehidupan masyarakat Islam Indonesia. Secara historis, pembuatan KHI bertujuan untuk memberikan kepastian hukum bagi para justisiabel dan hakim-hakim pengadilan agama dalam perkara-perkara perdata tertentu di kalangan umat Islam Indonesia. Kepastian hukum dalam Islam menurut Warkum Sumitro adalah kesatuan hukum yang berlaku di lingkungan pengadilan agama. Di mana sebelum KHI terbit, hukum Islam yang diterapkan di peradilan agama simpang 
Nur Aisyah

siur yang disebabkan oleh perbedaan pendapat para ulama dan para hakim di peradilan agama. Akibatnya bisa terjadi terhadap perkara yang sama, karena perbedaan tempat dan hakim yang menanganinya, putusannya menjadi berbeda. ${ }^{25}$ Kemudian Rofiq mengatakan bahwa keberadaan KHI lebih didasarkan dalam rangka menyiapkan pedoman yang seragam (unifikasi) bagi hakim Pengadilan Agama dan menjadi hukum positif yang wajib dipatuhi oleh seluruh bangsa Indonesia yang beragama Islam. ${ }^{26}$ Dengan secercah harapan agar tidak lagi terjadi kesimpangsiuran dalam memutuskan suatu perkara.

Maka dari itu, tidak berlebihan bila KHI menjadi suatu hal yang sangat dinantikan. Karena, dalam konteks Indonesia, peradilan agama sudah berusia cukup tua, akan tetapi tidak memiliki buku standar yang dapat dijadikan rujukan layaknya KUHPer atau KUHP. Untuk itulah, menurut Munawir Sadzali, ${ }^{27}$ perlu dibentuk suatu produk hukum yang dapat dijadikan landasan yang pada tahun 1985 pemerintah memprakarsai proyek KHI dan diselesaikan pada tahun 1988. Adapun proses penyusunan KHI telah melibatkan representasi dari kalangan umat Islam (Ulama, Ormas, Perguruan Tinggi dan sebagainya). Acuan yang digunakan dalam pembuatan KHI adalah al-Quran dan Sunnah, pendekatan kompromi dengan hukum adat, dan merumuskan suatu yang baru dan belum terdapat pada nash.

Lebih lanjut, Munawir Sadzali ${ }^{28}$, mengatakan bahwa proyek pembuatan KHI ini diketuai oleh Bustanul Arifin dengan menempuh beberapa langkah diantaranya adalah, menyiapkan permasalahan (masail), membahas buku-buku Fiqh, menelusuri sejarah yurisprudensi Islam dan melakukan studi banding. Fatwa-fatwa ulama dari berbagai ormas dan lembaga fatwa lainnya, kemudian wawancara dengan beberapa ulama, yurisprudensi kumpulan fatwa Peradilan Agama yang terdiri dari 15 buku dan hukum Islam yang dipraktekkan di negara-negara muslim di Timur Tengah. Setelah dilaporkan kepada ketua Mahkamah Agung dan Menteri Agama pada tahun 1978 yang diteruskan dengan lokakarya pada tahun 1988. Setelah lokakarya itu, diadakan penambahan pada konsep KHI.

Kemudian bila diperhatikan, antara jenjang pembuatan dan pengesahan KHI terdapat rentang waktu yang sangat panjang ( 6 tahun). Hal itu dikarenakan KHI belum memiliki baju hukum yang kuat berupa Undang-Undang Peradilan Agama (UUPA). Maka setelah UUPA dibuat yang tentunya menghadapi berbagai pro-kontra, dan KHI dianggap sempurna maka, proyek antara Mahkamah Agung dan Menteri Agama itu kemudian ditandatangani Presiden berupa Inpres No. 1 tahun 1991 tepatnya pada tanggal 10 Juni 1991. Adapun sasaran proyek ini lanjut mantan Menteri Agama ini adalah mempersiapkan rancangan buku hukum dalam bidang Perkawinan, Waris dan Wakaf.

Setelah KHI disahkan dan diberlakukan maka, kerancuan yang terserak perlahan dapat diatasi, di mana pada awalnya para hakim memutuskan perkara dengan

\footnotetext{
${ }^{25}$ Warkum Sumitro, Perkembangan Hukum Islam di Tengah Kehidupan Sosial Politik di Indonesia, (Malang: Bayumedia Publishing, 2005), h. 182.

${ }^{26}$ Ahmad Rofiq, Hukum Islam di Indonesia (Cet.III; Jakarta: Pt Grafindo Persada, 1998), h. 43

${ }^{27}$ Munawir Sadzali dalam Didin Muttaqien, dkk (ed.), Peradilan Agama dan Kompilasi Hukum Islam dalam Tata Hukum Indonesia (Yogyakarta: UII Press, 1993), h. 2.

${ }^{28}$ Munawir Sadzali dalam Didin Muttaqien, dkk (ed.), Peradilan Agama dan Kompilasi Hukum Islam dalam Tata Hukum Indonesia.
} 
latar belakang mazhab masing-masing, yang berdampak pada jurang disparatis putusan-putusan yang jauh dari rasa keadilan, perlahan pupus. Pada dasarnya, memang disadari bahwa banyak sekali kekurangan dalam KHI, namun kurang bijak bila diabaikan ajaran Ushul Fiqh, mala yudraku julluhu latudraku kulluh (apa yang tidak bisa dipenuhi semuanya, jangan ditinggalkan semuanya). Karena kehadiran KHI dianggap untuk mempertegas Peraturan Pemerintah sebelumnya baik tentang perkawinan (No. 9/1975), Wakaf maupun Waris.

Terlepas dari kekurangan draf KHI, sebagaimana menurut Amir Mu'alim², bahwa KHI terkesan malu-malu dan tidak terhormat dan tumpang tindihnya peraturan yang ada yang kemudian ditambah oleh Muhammad Amin Suma ${ }^{30}$, dengan mengatakan bahwa Inpres yang dalam tertib hukum Indonesia sangat jauh di bawah Undang-Undang, kita membuka tangan dengan lebar untuk menerimanya.

Betapa tidak, bila ditilik pendapat Ahmad Rofiq ${ }^{31}$ dengan mengutip ungkapan Abdurrahman yang mengatakan bahwa dalam konsideran Instruksi Presiden dinyatakan bahwa ulama Indonesia dalam lokakarya yang diselenggarakan di Jakarta telah menerima baik rancangan buku KHI, bahwa KHI tersebut oleh instansi pemerintah dan oleh masyarakat yang memerlukannya, dapat digunakan sebagai pedoman dalam menyelesaikan masalah-masalah di bidang tersebut. Oleh karena itu, KHI perlu disebarluaskan.

Selanjutnya, dengan menunjuk Pasal 4 (1) UUD 1945 "Presiden RI memegang kekuaasaan pemerintahan menurut UUD" Presiden menginstruksikan kepada Menteri Agama untuk: Pertama, menyebarluaskan KHI yang terdiri dari buku perkawinan, kewarisan dan perwakafan sebagaimana telah diterima baik oleh para alim ulama Indonesia dalam lokakarya di Jakarta pada tanggal 2 sampai dengan 5 Februari 1988, untuk digunakan oleh instansi pemerintahan dan oleh masyarakat yang memerlukannya. Kedua, melaksanakan Instruksi ini dengan sebaik-baiknya dan dengan penuh tanggungjawab.

Jadi, lanjutnya, penekanan dari instruksi tersebut adalah penyebarluasan dan dipedomani. Secara tegas, masih menurut Ahmad Rafiq, memang tidak ada teks khusus berkenaan dengan kedudukan dan fungsi kompilasi tersebut. Namun, seakan-akan dari dua kata tersebut, kompilasi tidak mengikat. Artinya, masyarakat dan instansi dapat memakai dan dapat pula tidak memakainya. Hal ini, tentu tidak sesuai dengan latar belakang dari penetapan kompilasi ini. Karena itu, pengertian sebagai pedoman harus dipahami sebagai tuntutan atau petunjuk yang harus dipakai baik oleh Pengadilan Agama maupun warga masyarakat dalam menyelesaikan sengketa mereka dalam bidang hukum perkawinan, kewarisan, dan perwakafan.

Kemudian bila disimak bahwa produk pemikiran hukum Islam sejauh ini tidak hanya terletak pada Fiqh an-sich, akan tetapi sudah merambah pada fatwa, Putusan pengadilan dan Undang-undang. Pertanyaanya adalah, di mana posisi KHI bila mengacu pada uraian di atas? Amir Syarifuddin yang dikutip Ahmad Rofiq ${ }^{32}$

\footnotetext{
${ }^{29}$ Amir Mu'alim dalam Jurnal Unisia No. 48/XXVI/II/2003 yang berjudul Reformasi Peran Hukum Islam di Indonesia, h. 156.

${ }^{30}$ Muhammad Amin Suma dalam Jurnal Unisia No. 48/XXVI/II/2003 dengan judul Reformasi Peran Hukum Islam di Indonesia, h. 181.

${ }^{31}$ Ahmad Rofiq, Hukum Islam di Indonesia (Cet. III; Jakarta: PT GrafindoPersada, 1998), h. 26.

${ }^{32}$ Ahmad Rofiq, Hukum Islam di Indonesia, h. 29.
} 
mengatakan bahwa kompilasi merupakan puncak pemikiran Fiqh Indonesia. Sebab, yang terjadi sebenarnya adalah perubahan bentuk dari kitab-kitab Fiqh menjadi terkodifikasi dan terunifikasi dalam KHI yang substansi muatannya tidak banyak mengalami perubahan.

Dalam hal ini, Rofiq mengatakan bahwa kompilasi yang sering disebut sebagai Fiqh dalam bahasa perundang-undangan merupakan karya bersama ulama dan umat Islam Indonesia. Karena itu, hendaknya ia dipahami dan ditempatkan sebagai pedoman hukum yang dijadikan referensi hukum dalam menjawab setiap persoalan hukum yang muncul, baik di Pengadilan Agama maupun di masyarakat. Namun, lanjut Rofiq, mengingat kompilasi ditegaskan melalui Instruksi Presiden maka kompilasi lebih dekat sebagai perundang-undangan. ${ }^{33}$

Hakim dalam hal ini menurut Prof. Atho Mudzhar dalam Satria Effendi adalah yang telah ditakdirkan harus belajar sepanjang hayatnya. Prof. Atho Mudzhar, mengutip pendapat Paul Scholten, sarjana Belanda yang mengatakan bahwa putusan Hakim itu adalah putusan dari akal pikiran dan hati nurani. Kalau cacat sedikit saja, maka putusannya akan menjadi siksaan kepada rasa keadilan masyarakat. ${ }^{34}$

\section{Menurut UU Perkawinan}

1) Pengertian perkawian Menurut Undang-Undang No.1 Tahun 1974

Sebagaimana diuraikan dalam Pasal 1 Undang-Undang Nomor 1 Tahun 1974 tentang Perkawinan, pengertian perkawinan adalah ikatan lahir batin antara seorang pria dan wanita sebagai suami istri, dengan tujuan membentuk keluarga (rumah tangga) yang bahagia dan kekal berdasarkan Ketuhanan Yang Maha Esa.

Pencantuman berdasarkan Ketuhanan Yang Maha Esa, adalah karena Negara Indonesia berdasarkan kepada Pancasila yang sila pertama adalah Ketuhanan Yang Maha Esa. Sampai di sini tegas dinyatakan bahwa perkawinan mempunyai hubungan yang erat sekali dengan agama, kerohanian, sehingga perkawinan bukan saja mempunyai unsur lahir/jasmani, tetapi juga mempunyai unsur batin/rohani. ${ }^{35}$

2) Pengertian Perkawinan Menurut Hukum Islam

Perkawinan adalah sunatullah berlaku bagi semua umat manusia guna melangsungkan hidupnya dan untuk memperoleh keturunan, maka agama Islam sangat menganjurkan perkawinan. Anjuran ini dinyatakan dalam bermacam-macam ungkapan yang terdapat dalam Al-Quran dan Hadist, hal ini sesuai dengan Pasal 2 Kompilasi Hukum Islam, bahwa perkawinan menurut hukum Islam adalah pernikahan akad yang kuat/mitzaaqah qhaliidhan untuk mentaati Perintah Allah SWT dan melakukannya merupakan ibadah. Selain itu perkawinan bertujuan untuk mewujudkan kehidupan rumah tangga yang sakinah, mawaddah dan warohmah.

Kata Mitzaaqan Qhaliidhan itu ditarik dalam Firman Allah SWT dalam surat An-Nissa ayat 21 yang artinya:

\footnotetext{
${ }^{33}$ Ahmad Rofiq, Hukum Islam di Indonesia, h. 31.

${ }^{34}$ Atho Mudzhar dalam Satria Effendi, Problematika Hukum Keluarga Islam Kontemporer, Edisi I (Jakarta: Kencana, 2004), h. xxii.

${ }^{35}$ Muhammad Idris Ramulyo, Hukum Perkawinan Islam: Suatu Analisis dari Undang-Undang No.1 Tahun 1974 dan Kompilasi Hukum Islam, Bumi Angkasa, Jakarta, h. 2.
} 


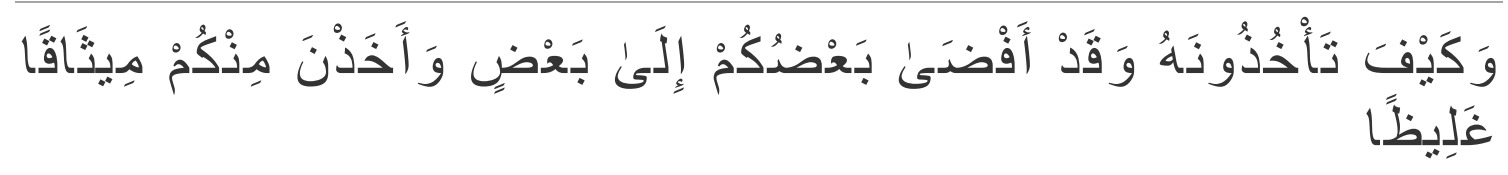

Terjemahan:

"Bagaimana kamu akan mengambilnya kembali, padahal sebagaian kamu telah bergaul (bercampur) dengan yang lain sebagai suami istri dan mereka (istri-istrimu) telah mengambil dari kamu perjanjian yang kuat"

Maksud perkataan nikah sebagaimana yang terdapat pada ayat tersebut bukan merupakan perjanjian yang biasa, melainkan suatu perjanjian yang kuat.

Ditinjau dari sudut hukum adat, Ter Haar memberi pandangan yang berbeda dengan menyatakan, bahwa perkawinan tidak semata-mata sebagai perikatan perdata, tetapi juga merupakan perikatan adat dan sekaligus perikatan kekerabatan dan ketetanggaan. Perkawinan oleh karenanya tidak hanya membawa akibat dalam hukum keperdataan, seperti hak dan kewajiban suami-istri, harta bersama, kedudukan anak, hak dan kewajiban orang tua, tetapi juga menyangkut hukum adat. ${ }^{36}$ Sementara menurut hukum agama, adalah perbuatan yang suci sebagai suatu perikatan jasmani dan rohani.

Kitab Undang-Undang Hukum Perdata tidak memberikan definisi yang jelas mengenai pengertian perkawinan, kecuali memandang perkawinan dalam hukum perdata saja.

Sesuai dengan Pasal 2 ayat (1) Undang-Undang No. 1 tahun 1974, bahwa perkawinan sah apabila dilakukan menurut hukum masing-masing agamanya dan kepercayaan itu, maka dari itu perceraian adalah sah apabila dilakukan menurut hukum masing-masing agama dan kepercayaaannya, sehingga dapat di katakan perceraian merupakan malapetaka yang perlu, untuk tidak menimbulkan malapetaka lain yang lebih besar bahayanya, dan perceraian juga harus dicatat menurut peraturan perundang-undangan yang berlaku.

3). Putusnya Perkawinan

\section{Menurut Undang-Undang No.1 Tahun 1974}

Sebelum membicarakan masalah putusnya perkawinan, ada baiknya dibicarakan terlebih dahulu (secara umum) perkawinan itu sendiri. Pengertian perkawinan menurut Sayuti Thalib, adalah suatu perjanjian suci, kuat dan kokoh untuk hidup bersama secara sah antara laki-laki dan perempuan untuk membentuk keluarga yang kekal, di mana suami istri harus saling menyant uni, mengasihi, dalam keadaan aman dan penuh kebahagian, moral, spiritual dan materil berdasarkan Ketuhanan Yang Maha Esa. ${ }^{37}$

\footnotetext{
${ }^{36}$ Hilman Hadikusuma, Hukum Perkawinan Indonesia Menurut Pandangan Hukum Adat, Hukum Agama (Bandung: CV. Mandar Maju, 2003), h. 8.

${ }^{37}$ Muhammad Idris Ramulyo, Hukum Perkawinan Islam: Suatu Analisis dari Undang-Undang No.1 Tahun 1974 dan Kompilasi Hukum Islam, (Jakarta: Bumi Angkasa, t.thn), h. 2.
} 
Nur Aisyah

Pada prinsipnya pokok-pokok perkawinan hendaknya $:^{38}$

1) Terdapat pergaulan yang ma'ruf antara suami-istri dan saling menjaga rahasia masing-masing serta saling membantu.

2) Terdapat pergaulan yang aman dan tentram (sakinah).

3) Pergaulan yang saling mencintai antara suami istri (mawaddah).

4) Pergaulan yang disertai rasa santun menyantuni terutama setelah tua mendatang (rahmat).

\section{PENUTUP}

\section{Kesimpulan}

1. Peranan Hakim Pengadilan Agama dalam penerapan Hukum Islam adalah sebagai alat untuk menjaga keselarasan komponen-komponen hukum lainnya, secara fungsional. Dengan kata lain, tegaknya Hukum Islam, ditentukan oleh kemampuan peranan hakim pengadilan agama dalam menyelaraskan perangkat hukum dan kesadaran hukum, sehingga tercipta ketertiban dan kepastian hukum di dalam masyarakat.

2. Usaha-usaha yang harus dilakukan oleh Hakim Pengadilan Agama, mengoptimalkan peranannya adalah pertama, mengupayakan keselarasan antara ketertiban dan kepastian hukum. Kedua, mengupayakan fungsionalisasi keselarasan tersebut di dalam lingkungan yang dihadapi. Ketiga, mengupayakan efektifikasi hukum tersebut di dalam masyarakat. Di samping itu, hakim pengadilan agama juga harus memiliki kesadaran, pengetahuan dan keterampilan sosial yang memadai, sebab tuntutan yang muncul dari perubahan masyarakat menuntut peranan hakim pengadilan agama tidak hanya sekedar menyelesaikan benturan kepentingan di dalam masyarakat, tetapi juga mengarahka perubahan yang ada. Dengan kata lain, hakim pengadilan agama dituntut untuk memainkan peranannya, baik sebagai tenaga profesional maupun sebagai perencana sosial.

\section{Implikasi}

1. Hakim Pengadilan Agama harus memahami upaya Penegakan hukum Islam, baik dalam skala lokal maupun global, intensitas pemahaman yang mendalam atas situasi sosio kultur yang berada di dalam lingkup kekuasaannya. dalam meningkatkan intensitas pemahaman terhadap situasi tersebut, dibutuhkan suatu kerangka berpikir yang mampu memformulasikan fakta-fakta yang dihadapi masyarakat.

2. Hakim Pengadilan Agama juga dituntut untuk mampu berpikir realistis. Dibutuhkan suatu jalur pikiran yang mampu menjembatani aspek ideal dan aspek praktis, karena upaya Penegakan Hukum Islam bersifak praktis, yaitu yang diilhami oleh kerangka ideal, dan bergerak menurut garis rencana serta program sebagai jembatannya, maka jembatan yang tepat adalah beranjak dari realitas.

${ }^{38}$ Muhammad Idris Ramulyo, Hukum Perkawinan Islam: Suatu Analisis dari Undang-Undang No.1 Tahun 1974 dan Kompilasi Hukum Islam, h. 4. 


\section{DAFTAR PUSTAKA}

Soekanto, Soerjono. "Ilmu-ilmu Hukum dan Pembangunan Hukum," Analisis Pendidikan. Jakarta : Departemen Pendidikan dan Kebudayaan, 1983.

Deden Effendi, Kompleksitas Hakim Pengadilan Agama. Jakarta : Departemen Agama R.I., 1985.

Daniel S. Lev, Peradilan Agama di Indonesia: Studi tentang Landasan Politik Lembaga-Lembaga Hukum, alih bahasa H. Zaini Ahmad Noeh. Jakarta: PT Intermasa, 1980.

T. M. Hasbi Ash Shiddiqi, Peradilan Hukum Acara Islam. Bandung: PT Al-Maarif, 1964.

Bambang Marhijanto, Kamus Lengkap Bahasa Indonesia Populer. Surabaya: CV. Bintang Timur, 1996.

Maurice Duverger, Sosiologi Politik, alih bahasa Daniel Dhakidae. Jakarta: CV Rajawali, 1981.

Abdul Kadir Muhammad, Hukum Acara Perdata Indonesia. Bandung: Citra Aditya Bakti, 1992.

UU No. 48 Tahun 2009 tentang Kekuasaan Kehakiman. Surabaya: Karina, 2004.

http://advosolo.wordpress.com/2010/05/15/kekuasaan-peradilan-agama/

Cik Hasan Bisri, Peradilan Agama Di Indonesia. Cet. II (Jakarta: PT. RajaGrafindo Persada, 1998.

Yahya Harahap, Hukum Acara Perdata tentang Gugatan, Persidangan, Penyitaan, Pembuktian dan Putusan Pengadilan. Cet.II; Sinar Grafika, Jakarta, 2005.

Abdul Manan, Penerapan Hukum Acara Perdata di Lingkungan Peradilan Agama. Cet.II; Yayasan al-Hikmah, Jakarta, 2001.

Ahmad Mujahidin, Pembaruan Hukum Acara Perdata Peradilan Agama dan Mahkamah Syari'ah di Indonesia. Cet.I; IKAHI, Jakarta, 2008.

Mimbar Hukum Islam No.66 Desember 2008, h, 182.

Departemen Agama RI, Berita Acara Persidangan Peradilan Agama, Direktorat Jenderal Pembinaan Kelembagaan Agama Islam. Cet.1 th. 1987..

Yurisprudensi MARI. Tahun 2003.

Warkum Sumitro, Perkembangan Hukum Islam di Tengah Kehidupan Sosial Politik di Indonesia. Malang: Bayumedia Publishing, 2005.

Ahmad Rofiq, Hukum Islam di Indonesia. Cet.III; Jakarta: Pt Grafindo Persada, 1998

Munawir Sadzali dalam Didin Muttaqien, dkk (ed.), Peradilan Agama dan Kompilasi Hukum Islam dalam Tata Hukum Indonesia. Yogyakarta: UII Press, 1993.

Amir Mu'alim dalam Jurnal Unisia No. 48/XXVI/II/2003 yang berjudul Reformasi Peran Hukum Islam di Indonesia. 
Peranan Hakim Peradilan Agama ...

Nur Aisyah

Muhammad Amin Suma dalam Jurnal Unisia No. 48/XXVI/II/2003 dengan judul Reformasi Peran Hukum Islam di Indonesia.

Atho Mudzhar dalam Satria Effendi, Problematika Hukum Keluarga Islam Kontemporer, Edisi I. Jakarta: Kencana, 2004.

Muhammad Idris Ramulyo, Hukum Perkawinan Islam: Suatu Analisis dari UndangUndang No.1 Tahun 1974 dan Kompilasi Hukum Islam. Jakarta: Bumi Angkasa.

Hilman Hadikusuma, Hukum Perkawinan Indonesia Menurut Pandangan Hukum Adat, Hukum Agama. Bandung: CV. Mandar Maju, 2003.

Muhammad Idris Ramulyo, Hukum Perkawinan Islam: Suatu Analisis dari UndangUndang No.1 Tahun 1974 dan Kompilasi Hukum Islam. Jakarta: Bumi Angkasa, t.thn. 